\title{
Cuento de los gatos
}

\section{Andrea Pérez, Rachel Wilkins}

Había una vez un gato negro que se llamaba Nene. Él vivía con su dueño, un marinero activo en una base llamada Twenty Nine Palms, en California. Nene pasaba mucho tiempo con su dueño en California y era muy feliz allí con él. Un día, su dueño y su esposa buscaron a Nene y lo pusieron en una jaula y permaneció en el baúl de su Jeep por dos días. Cuando Nene salió del baúl, estaban en un lugar diferente.

Ahora Nene estaba en una casa nueva con cuatro gatos y dos perros que no lo querían conocer. Nene pasó una semana en un cuarto con su dueño, pero un día su dueño se fue y nunca regresó.

Nene tenía hambre y tenía que salir del cuarto para buscar alimento. Un día salió a buscar comida y encontró a otro gato devorando el plato de comida. Era una gata que se llamaba Kitty y permitió que Nene comiera con ella. Se convirtieron en amigos. Después de almorzar con Kitty, Nene estaba explorando la casa y encontró un gato que se llamaba Chispos. Nene se acercó a Chispos, pero a Chispos no le gustó eso. Chispos rasguñó a Nene y no quiso que se acercara a sus lugares en la casa.

Nene estaba triste porque el gato más popular de la casa no lo quería y no sabía por qué. Nene sólo quería ser su amigo. Buscó a Kitty después y ella le explicó que Chispos era como el jefe de todas las mascotas de la casa y no le gustaba que lo molestaran. Al día siguiente, los nuevos dueños de la casa dejaron comida para su bebé en la mesa. Era un caldo de pollo para bebés, pero a los gatos les gustó el olor del pollito. Chispos trató de comer el pollo, pero Nene brincó encima de la mesa para decirle a Chispos que el pollo era para el bebé, no para los gatos. Mientras se peleaban los dos gatos, uno de los dueños regresó a la cocina y Chispos saltó de la mesa, pero Nene no pudo escapar a tiempo. Los dueños regañaron a Nene porque pensaban que él se quería comer el caldo.

Un día Nene decidió hablar con Chispos y preguntarle por qué no quería compartir con las otras mascotas. "No es que no quiera compartir, sino que los demás me tienen miedo y piensan mal de mí". Cuando Nene escuchó esto le sugirió a Chispos pasar tiempo con él para que los demás vieran que no era odioso. Chispos no supo que decir. Había estado solo y triste por mucho tiempo. Se le hizo raro que alguien quisiera acercarse y pasar tiempo con él.

Poco a poco Nene y Chispos se empezaron a conocer y Kitty se incorporó al pequeño grupo. Chispos, Kitty y Nene se hicieron amigos y también pasaban tiempo juntos con el bebé. Algunos meses después, el marinero regresó para llevar a Nene de vuelta a California. Nene no se quería ir porque había hecho nuevos 
amigos y buenos recuerdos con Chispos y Kitty. El marinero recogió las cosas de Nene y las subió al Jeep para regresar a su hogar. Nene le dijo adiós a sus nuevos amigos y se fue contento sabiendo que dejó una casa llena de amistad y amor.

\section{Moraleja}

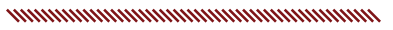

"Las personas siempre encuentran lugares donde pueden estar bien". 